\title{
EDITORIAL
}

\section{Transfer Pricing in the Digital Economy}

Publication of this special issue that is dedicated to transfer pricing ${ }^{1}$ coincides in time with the publication of the $\mathrm{OECD} / \mathrm{G} 20$ conclusions on the allocation of taxing rights and the future of the international tax system in the digital economy. Transfer pricing is at the core of the aforementioned OECD/G20 discussions and conclusions (Pillar I). Therefore, it is hardly possible to discuss transfer pricing without also debating the digital economy, the future of the international tax system, and the role of the market state.

Three options for connecting elements, all of them targeting allocation of taxing rights to the market state, were proposed by the OECD in February and May 2019² under its Pillar I: international taxation on the basis of a significant market presence; taxation according to the value of user contributions; and profit allocation to market intangibles.

'User participation' implies selecting those digital business (also called highly digitalized business) for which users allegedly create value and, therefore, ring fencing, unless a pre-determined formula based on non-routine or residual profits back to the user country would apply. ${ }^{3}$ The 'significant economic presence' proposal combines a revenue threshold in the market country with a user based factor, a digital factor, or other market related factors and could rely on a fractional apportionment method that is more or less favourable to the market country. ${ }^{4}$ The 'marketing intangibles' approach claims that a non-resident entity can actively intervene in the market country and develop market intangibles therein. ${ }^{5}$ Allocation of taxing rights to the market country could rely on a residual profit split analysis or a modified residual profit split method based on a predetermined formula. ${ }^{6}$

All three options mentioned above potentially rely on transfer pricing, even if they reconsider the latter, go beyond the arm's length standard and develop into some form of aggregate taxation. ${ }^{7}$

The articles below illustrate this interconnection. Wolfgang Schön (One Answer to Why and How to Tax in Digitalized Economy) assesses the merits of the OECD proposals considering revenue, fairness, and efficiency as well as the issue on the relevant connection to territory. Schön claims that corporate income tax is a tax on return on country-specific investment, and the profit share should include the riskless rate of return, the risk premium, and the rent. ${ }^{8}$ Vikram Chand analyses the OECD 2019 public discussion and the subsequent program of work documents, reflecting on the 'marketing intangible' and a new nexus rule attached to the source. He further elaborates on a rebuttable safe harbour that is constructed on a return on sales or operating profit margin.

Isabel Verlinden et al focus on the 'development, enhancement, maintenance, protection and exploitation' (DEMPE) concept in the context of transfer pricing and a value chain analysis and its merits in capturing value related to the technological advances and new business

\section{Notes}

I would like to thank Vikram Chand for coordinating this special issue with me.

OECD, Addressing the Tax Challenges of the Digitalization of the Economy - Public Consultation Document (OECD/G20 Base Erosion and Profit Shifting Project, 2019); OECD, Programme of Work to Develop a Consensus Solution to the Tax Challenges Arising from the Digitalization of the Economy (OECD/G20 Base Erosion and Profit Shifting Project 2019).

OECD, Addressing the Tax Challenges of the Digitalization of the Economy - Public Consultation Document, at 18-21, 24, 27; See in this issue: V. Chand, Allocation of Taxing Rights in the Digitalized Economy: Assessment of Potential Policy Solutions and Recommendation for a Simplified Residual Profit Split Method, at 1023 et seq.

4 OECD, Addressing the Tax Challenges of the Digitalization of the Economy - Public Consultation Document, at 50; V. Chand, Allocation of Taxing Rights in the Digitalized Economy, cit, n. 3 at $1029-1032$.

OECD, Addressing the Tax Challenges of the Digitalization of the Economy - Public Consultation Document, at 31-32.

OECD, Programme of Work to Develop a Consensus Solution ..., at 28.

See W. Schön, One Answer to Why and How to Tax the Digitalized Economy, in this issue, at 1018 et seq.

Ibid. 
models. ${ }^{9}$ K. Ming Ho and C. Turley discuss the value creation principle. G. Lambert, A. Pletz, and G. Dettmann analyse the OECD approach on financial transactions in an intragroup context. ${ }^{10} \mathrm{P}$. Klaassen and A. Bobeldijk debate the effective tax rate in relation to the Country-by-Country Reporting regime. In turn, Scott Wilkie (The Way we Were? The Way We Must $\mathrm{Be}$ ?) reflects on the evolution of transfer pricing and the implications of a fractional apportionment as it is currently being discussed by the OECD. ${ }^{11}$

This issue also includes a section on Tax in History (the 100th anniversary of the Belgian Income Tax by Possoz Buyaerts and Traversa), two case-notes (a landmark decision by the German Federal Tax Court on the arm's length principle and a VAT case), and a literature review.
The OECD/G20 is bringing some light on the evolution of the current tax system, however, the authors in this issue depart from the OECD ongoing work. They do not suggest a revolutionary approach but rather rely on an evolution of the current international tax system. This evolution, however, acknowledges that the digital economy requires a different approach towards transfer pricing based on the arm's length principle.

Complexity and double taxation are excessive consequences for minimum standards in the context of multilateral consensus. The BEPS project announced the complexity, and the recent developments increase it. It is rationally difficult to celebrate the announced achievements on the reform of transfer pricing.

Ana Paula Dourado General Editor

\section{Notes}

9 I. Verlinden, S. De Baets \& V. Parmessar, Grappling with DEMPEs in the Trenches, in this issue, at 1042.

10 OECD, Public Discussion Draft Financial Transactions, BEPS Actions 8-10 (3 July to 7 Sept. 2018), https://www.oecd.org/tax/beps/BEPS-actions-8-10-transfer-pricingfinancial-transactions-discussion-draft-2018.pdf; G. Lambert, A. Pletz \& G. Dettmannm, Implicit Support and Its Implications on Guarantee Fee Pricing: Fact or Fiction, in this issue, at 1077 et seq.

11 J. Scott Wilkie, The Way We Were? The Way We Must Be? The 'Arm's Length Principle' Sees Itself (for What It Is) in the 'Digital' Mirror, at 1087 et seq. 